\title{
After McCahon at Auckland City Art Gallery: Canonisation and the Market in the 1980s
}

\author{
ANNA PARLANE
}

\begin{abstract}
Can New Zealand postmodernism be described as a post-McCahon condition? Curator Christina Barton's exhibition after McCahon: some recent configurations in art (1989), at Auckland City Art Gallery, was a critical response to McCahon's canonisation, registering internal diversity within an institution deeply invested in this status. Strategically invoking McCahon's name enabled Barton to smuggle a group of younger artists into ACAG's exhibition programme. The artists in After McCahon explored poststructuralist theory, an expansion of institutional critique, post-punk practices and decolonial politics. These discourses of the 1980s supported the production of works dripping with postmodern irony and acutely conscious of the institutional authority amplifying McCahon's voice and certifying his blue-chip status.
\end{abstract}

In 1989 Christina Barton, then Assistant Curator of Research Collections at Auckland City Art Gallery, curated her inaugural exhibition at the Gallery. ${ }^{1}$ after McCahon: some configurations in recent art was a group show of early- and mid-career artists that responded to the work and mythology of Colin McCahon, at that point easily the most dominant figure in New Zealand art over the previous twenty years. The show signalled the intellectual ambition of its curator, whose appraisal of the art of her peers was informed by poststructuralist theory and aimed - as I will argue - to describe a local form of postmodernism as a post-McCahon condition. after McCahon is interesting, therefore, as an argument about periodisation in New Zealand art history. However, the show can also be understood as a postmodern critique of artistic authorship and canonformation, and therefore as a critical intervention into the exhibition programme of the Auckland City Art Gallery. Over the preceding decades, but with particular intensity through the 1980s, the ACAG had invested substantially in building a collection of McCahon's works and in an exhibition programme ensuring that his "reputation as New Zealand's greatest artist" remained "unquestionable." Such institutional support and the concurrent exponential increase in McCahon's prices altered the meaning of his works. Barton's exhibition presented art by a younger generation already cognisant of their entanglement with the market, and it emerged as a critical voice out of an institutional context deeply invested in McCahon's canonisation.

after McCahon followed McCahon in several different ways. Firstly, Barton's exhibition registered the impact of McCahon's oeuvre on New Zealand art practice, acknowledging the extent to which - as a matter of simple consequence - artists born in the generations following McCahon must reckon with an art history centred on his work. after McCahon also literally followed the Gallery's blockbuster retrospective of McCahon's work, Colin McCahon: Gates and Journeys, curated by Alexa Johnston with Gordon H. Brown, Wystan Curnow and Tony Green, which opened in November 1988. Years in the making and led by a curatorial team that included the Gallery's senior curator together with the leading scholars on McCahon's work, Gates and Journeys became a memorial exhibition after the artist's death in May 1987. Barton's show, which opened in some of the same gallery spaces two months after Gates and Journeys closed, was thus "after" McCahon in the most literal sense, chronologically and spatially.

Journal of New Zealand Studies NS31 (2020), 72-94 https://doi.org/10.26686/jnzs.v0iNS31.6679 
The modish lower case "a" at the start of Barton's exhibition title, after McCahon: some configurations in recent art signalled her interest in the tangled questions around precedence and antecedence explored in the poststructuralist writing of Jacques Derrida. Barton acknowledged her title's debt to the Derridean work of Auckland academic Laurence Simmons, and specifically his 1987 paper "after Titian: intertexuality and deconstruction in an early painting by Colin McCahon," which itself followed McCahon's Entombment (after Titian), 1947. ${ }^{3}$ Poststructuralism had filtered into New Zealand art and scholarship during the 1980s in the work of scholars like Simmons, Wystan Curnow, Francis Pound and Roger Horrocks as well as influential Australian publications like Art \& Text, and it provided a rich theoretical framework for Barton's examination of artistic authorship. ${ }^{4}$ after McCahon flirted with the suggestion that "after" can indicate deference or indebtedness to an authority, or a move towards supersession. The slipperiness of Barton's title helped to smooth the entry of her show into the ACAG exhibition programme: the implication that the exhibition might examine a younger generation's indebtedness to the Gallery's star artist was highly strategic. However, this slipperiness also caused some confusion as different institutional voices insisted on different interpretations.

In his preface to the exhibition catalogue, Gallery director Christopher Johnstone firstly took care to distinguish Barton's opinions from those of the institution: "In her selection and introduction Christina Barton ... addresses and elucidates issues in current art practice that are, in her opinion, especially of their time and place." In a striking departure from an institutional model in which the views of in-house curators are presented as synonymous with those of the institution itself, Johnstone declared Barton's curatorial stance to be independent of her employer. It is worth noting that no such declaration appears in Johnstone's preface to the catalogue for the McCahon blockbuster, Gates and Journeys. Here, he repeatedly used an inclusive "we" to refer simultaneously to himself, the curatorial team and the institution in general, also sometimes folding the entire audience of McCahon's art into this collective and unified subject position. In the catalogue for after McCahon however, having distanced himself and the Gallery from Barton's opinions, Johnstone proceeded to put words in her mouth: "Her theme is woven around the powerful presence of the work of Colin McCahon," he explained, "which she sees as a liberating influence rather than an obstacle to be overcome or a model to be worked through." Colin McCahon, it is clear, is not to be regarded as an obstacle but an influence. Johnstone insists that McCahon's work does not present a problem for a younger generation of artists to overcome; it is in fact the agent of their liberation. This opening clarification from the Gallery director was necessary, it seems, because Barton's own essay so lucidly demonstrated her interest in the problems associated with canonisation in general and McCahon's canonisation in particular. ${ }^{7}$

\section{after McCahon: The Exhibition}

This clash of perspectives also played out in the exhibition itself. While none of McCahon's works were included in the exhibition proper-his name doesn't appear in the catalogue's list of workshis The Fourteen Stations of the Cross, 1966, was installed immediately outside the entrance to the show. This was the decision of Alexa Johnston, who had led the curatorial team of Gates and Journeys and who Barton remembers was deeply involved in building the Gallery's collection of his work. For Barton, this was a problem. after McCahon was intended as "a way of leveraging something different into those same spaces, with the echo of that earlier show hovering only in visitor's memories. I didn't want an actual McCahon to be at the doorstep." 8 However, in the

Journal of New Zealand Studies NS31 (2020), $72-94$ https://doi.org/10.26686/jnzs.v0iNS31.6679 
physical exhibition spaces as in the exhibition's catalogue, a statement insisting on the "powerful presence" of McCahon was installed by a senior member of the Gallery's staff as a preface to Barton's work.

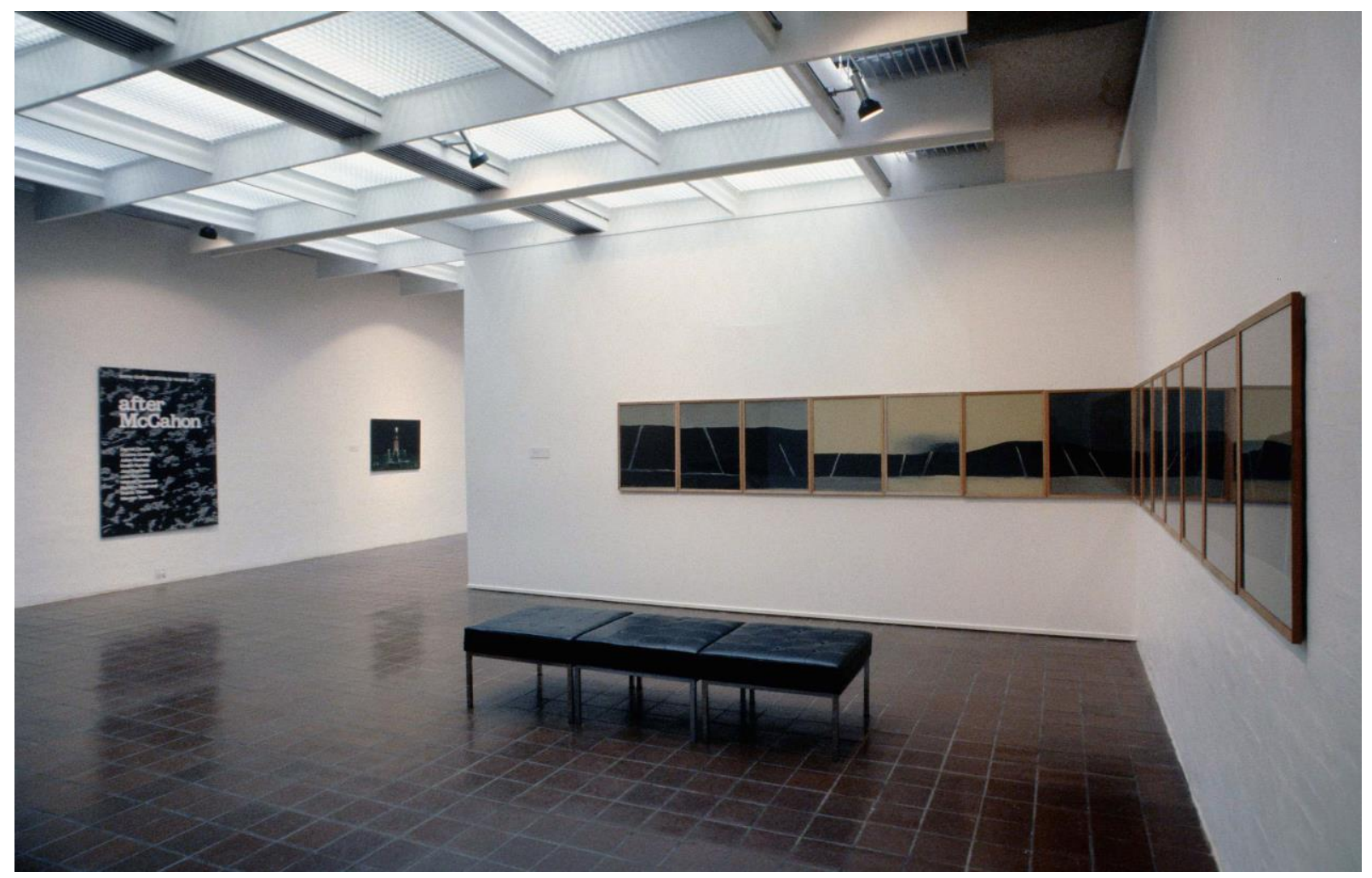

Figure 1. after McCahon: some configurations in recent art, 1989. Auckland City Art Gallery, curated by Christina Barton. Colin McCahon, The Fourteen Stations of the Cross, 1966, is installed to the right of the entrance to the exhibition; Michael Stevenson, Glowing Cross, Palmerston North, 1988, can be seen at the centre of the image. Image courtesy of Auckland Art Gallery Toi o Tāmaki.

Viewers were enticed into Barton's show by Michael Stevenson's Glowing Cross, Palmerston North, 1988. A night scene showing the floodlit cenotaph of Palmerston North's city square emerging out of lumpy greenery and flanked by street lights, the painting's apparent earnestness was typical of Stevenson's work at the time. Painted in a self-consciously naïve style, the symmetrical composition centrally positions the cenotaph's glowing cross in a trinity of light sources. The Christian message is obvious, even bordering on banal, and installed opposite the waterfalls of McCahon's Stations of the Cross - which also stage the penetration of darkness by a divine light - it echoed their religious symbolism. However, while Stevenson's folksy style and familiar imagery might initially have seemed approachable, in the artist's words, "rapidly after that first impression, the 'Welcome' mat is snatched away." Doubt creeps in: the suspicionnever resolved - that these apparently earnest works might in fact be a parody of a Sunday painter's religious art tends to increase with prolonged exposure. 


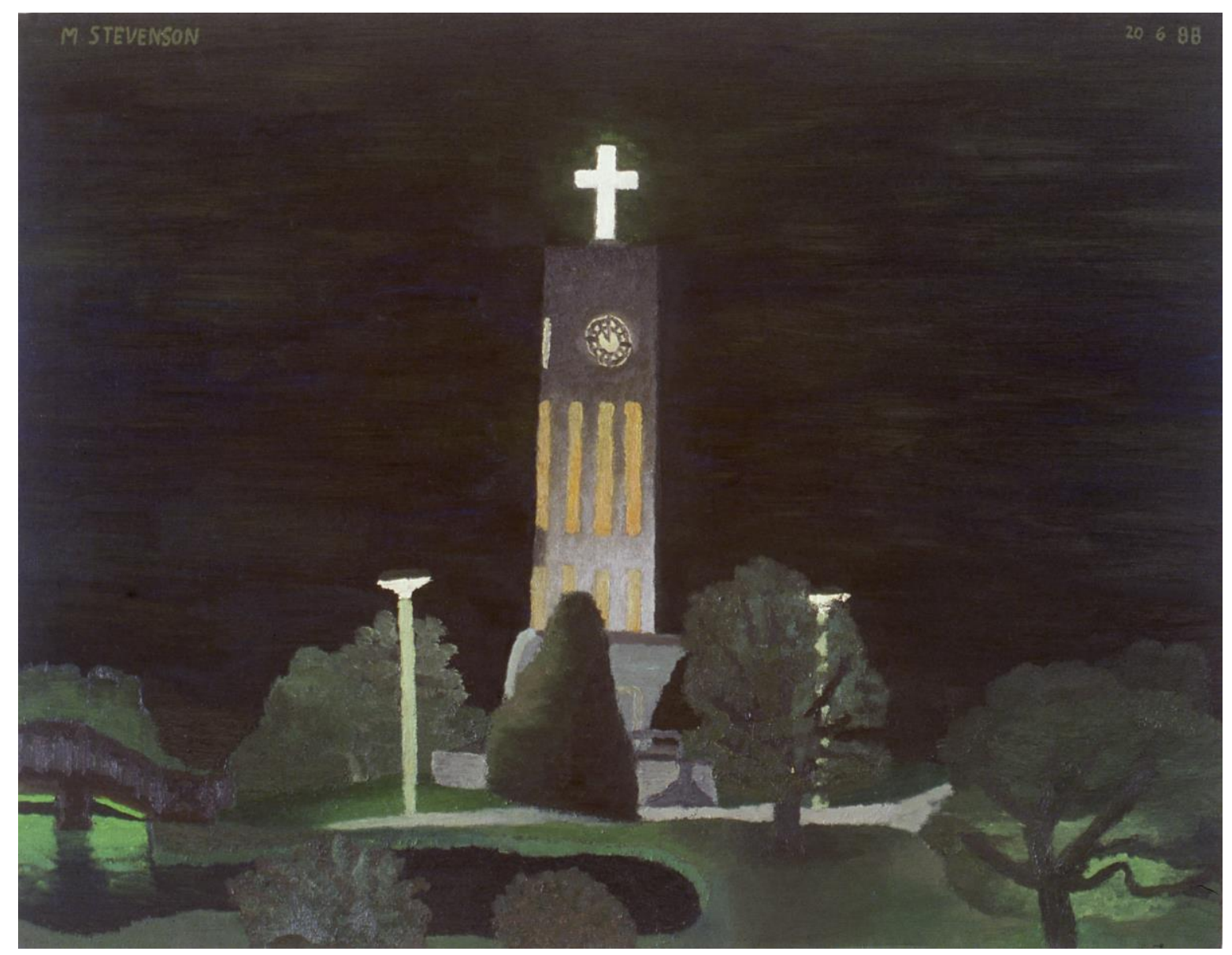

Figure 2. Michael Stevenson, Glowing Cross, Palmerston North, 1988. Oil on board, $69.9 \times 89.5 \mathrm{~cm}$. Collection of Te Manawa Museum Trust, New Zealand.

Glowing Cross presents the civic lighting of a small park in the regional backwater of Palmerston North as a religious vision, staging the moment at which the scales fell from the eyes of some imagined night-time wanderer. However, Stevenson's work stands in direct contrast to Gordon H. Brown's cryptoreligious interpretation of McCahon's oeuvre, which instantiated the artist as a Christ-like "prophet in the wilderness," modelling the transformation of mundane local reality into the millenarian promised land. ${ }^{10}$ The faux naivety of Stevenson's paintings lends them a selfcontradictory tone containing both rustic charm and caustic humour: at their best, they manage to be sincere and dryly ironic in equal measure. Glowing Cross's elevation of the everyday into sacredness is also, and equally, a descent into absurdity and a pantomime of conventional faith. Stevenson's Jesus Loves Us All (in Clinton), 1988, is similarly tinged with humour. The titular banner-JESUS LOVES US ALL - is strung above the window in a humble community church hall interior. However, as Stevenson shows, the banner is facing inwards, towards the congregation rather than the broader population. This affirmative message of Christ's universal love is here being used to define the chosen few (Jesus loves us all, in Clinton) rather than the beloved multitudes (Jesus loves us all in Clinton). Stevenson's faux-naïve style enabled an authorial stance that flickers between genuine religious feeling and wry observations of human folly. His works set the tone for Barton's show. 


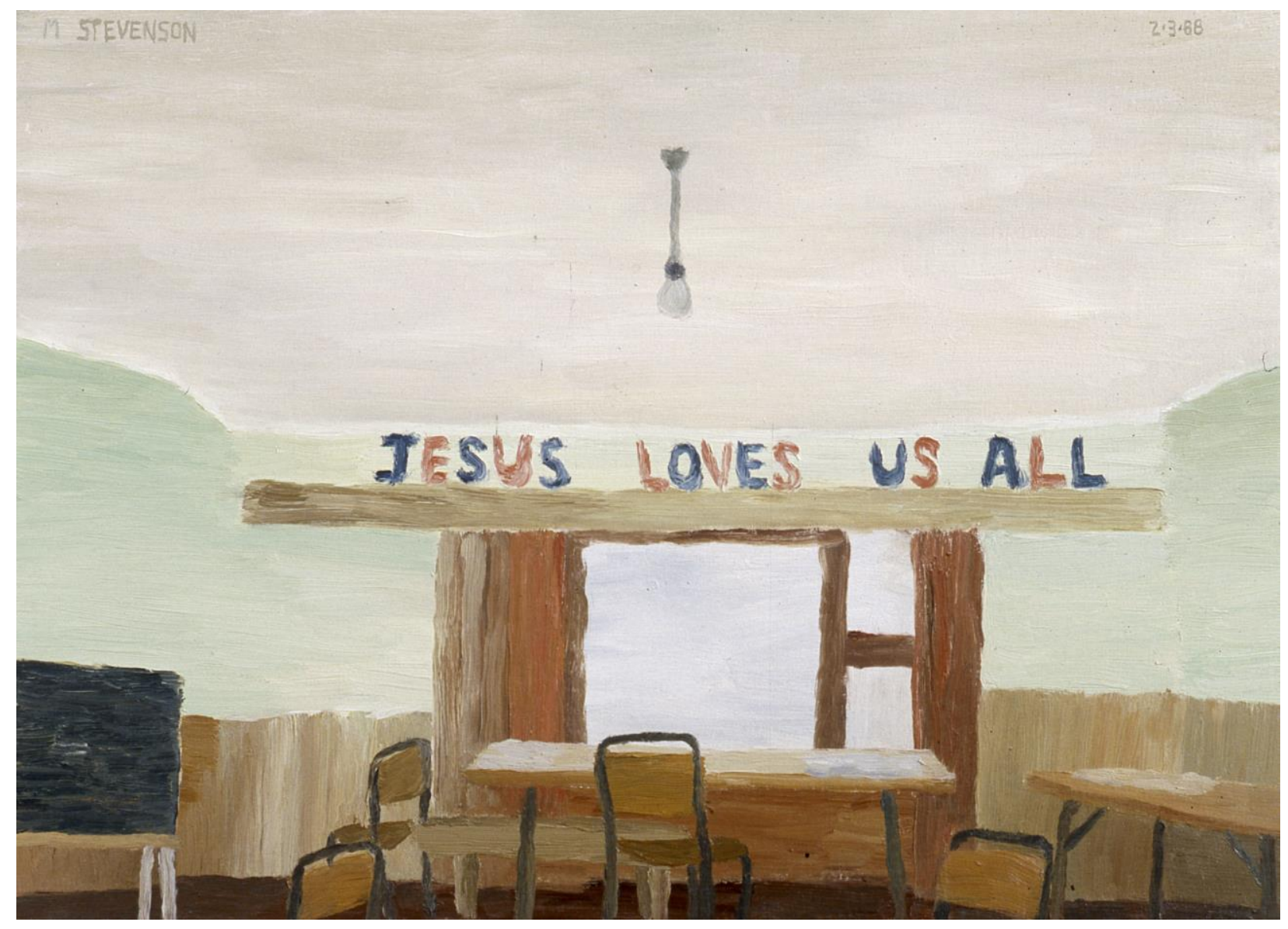

Figure 3. Michael Stevenson, Jesus Loves Us All: In Clinton, 1988. Oil on board, $50 \times 70 \mathrm{~cm}$. Collection of the artist.

after McCahon picked up on core McCahonian themes, such as Christianity and the representation of landscape, and it is possible to read the whole show fairly superficially as a spot-the-influence exercise. Works by Stevenson and Derek Cherrie at the exhibition's entrance gave a nod to questions of religion, as articulated and experienced through the everyday and local. Progressing through the exhibition, viewers encountered works by Emily Karaka, Imants Tillers, Jane Pountney and others exploring the representation of landscape and the use of written words in visual art. However, the exhibition was not simply a demonstration of McCahon's ideas taken up and dressed in the current fashions, no matter how much Christopher Johnstone may have wanted it to be.

In fact, the suggestion of McCahon's artistic influence contained in Barton's ambiguous title functioned largely as a Trojan Horse. As Francis Pound pointed out in his review of the show, the generation of artists most directly engaged with McCahon's influence were absent from after McCahon. ${ }^{11}$ Pound's own exhibition, New Image, 1983, had bundled together Richard Killeen, Ian Scott, Dick Frizzell and others as an emergent postmodern vanguard. ${ }^{12}$ As Pound has convincingly argued, and as Barton would have been well aware, it was these artists who first rejected the anxious, landscape-centric soul-searching of New Zealand paintings' nationalist and regionalist traditions. For artists like Scott and Killeen, "McCahon was a Gate, say, in its triple and 
indeterminable sense, of that which bars a way, and that which opens a way through, and which shapes a way." 13 Barton's exhibition advanced an argument about periodisation in New Zealand art history, but unlike New Image, the group of artists it presented was not one bounded by their response to questions posed by McCahon.

The question of faith, so central to McCahon's work, was not explored in depth. Barton didn't acknowledge, for example, the substantial theological differences between Stevenson's radical Pentecostal faith and McCahon's much more mainstream Christian beliefs. ${ }^{14}$ The most interesting conversation about landscape painting in the show took place between Imants Tillers and Emily Karaka, and barely, actually, involved McCahon at all. The rough-and-ready aesthetic and lowbudget materials used by many of the artists had at least as much to do with the degraded materiality of "xeroxed" imagery, post-punk visual culture, street art and 1980s neoprimitivism as it did with McCahon's builder's paper, house paint and unstretched canvases.

The McCahon that Barton's exhibition responded to was not the rich artistic resource that Johnstone imagined, nor was his work the thesis to a younger generation's antithesis, as it had been for the New Image artists. The McCahon that Barton's show was "after" was the mythic, towering figure constructed in Gates and Journeys. This was the artist whose handwritten inscriptions across the surface of his paintings - that immediately recognisable scrawl, the autographic mark par excellence - now registered as the pronouncements of canonical authority rather than idiosyncratic expressions of doubt or vulnerability. This was McCahon as "prophet in the wilderness"; protagonist of Gordon H. Brown's powerfully cryptoreligious art history; the sacrificial son of New Zealand's cultural philistinism; the artist who taught us to see.

\section{The McCahon Myth and the McCahon Market}

The story of McCahon's association with Auckland City Art Gallery is mythic. It dovetails with the popular narrative of the artist's struggle for recognition in a culturally conservative and hostile society, and with his ultimate triumph. Beginning, notoriously, with his 1953 appointment by director Eric Westbrook as a cleaner at the Gallery, McCahon took on the roles of gallery attendant and then curator in 1956. ${ }^{15}$ As curator and deputy director to Westbrook's successor, Peter Tomory, he held an increasingly prominent role within the institution until his departure in 1964. With his emphasis on exhibiting and collecting the work of contemporary New Zealand artists, McCahon helped to shape the character and priorities of the Gallery during a period in which it was widely recognised as the most dynamic cultural institution in the country. ${ }^{16}$

The development of McCahon's career and artistic reputation occurred in tandem with that of the ACAG, and also with a pioneering generation of commercial gallerists who established a market for local contemporary art. ${ }^{17}$ Through his work as an artist, teacher and curator, McCahon educated New Zealand's viewing public, helping audiences to perceive the value in his own and other contemporary artists' work. In this he was supported by his institutional connections and his relationships with his gallerists, which - it is worth emphasising-were closely related. In part via professional networks established through his role at ACAG, McCahon was closely involved with the formation of the nascent commercial gallery system. Jill Trevelyan describes how The Gallery (later Ikon Gallery), run by Don Wood and Frank Lowe, 
... was a popular hangout for students and artists, and had close links to the nearby Auckland City Art Gallery; indeed, the idea of opening a gallery had been suggested by [ACAG Director Peter] Tomory and his staff. McCahon, in particular, was very encouraging: having visited New York in 1958, he understood the role a dealer gallery could play in Auckland. It was he who provided a list of artists, and the first exhibition was opened by Tomory. ${ }^{18}$

Wood and Lowe had both been students in the painting classes McCahon ran after hours at ACAG, and he exhibited regularly at their gallery through the early 1960s. ${ }^{19}$ It was at Ikon in 1964 that McCahon met Peter McLeavey - then a small-scale but passionate collector of contemporary New Zealand art - inaugurating a friendship that would inspire the establishment of the Peter McLeavey Gallery in Wellington two years later. ${ }^{20}$ The artist Barry Lett, in partnership with Frank Lowe and Rodney Kirk Smith, opened Barry Lett Galleries as a successor to Ikon in 1965: Lett and McLeavey in particular were instrumental in developing a market for McCahon's work. ${ }^{21}$ With commercial representation in both Auckland and Wellington, from 1971 McCahon was able to support himself and his family from the sale of his art alone. ${ }^{22}$

Jill Trevelyan has described the extent to which the booming international art market in the 1980s affected the prices of New Zealand artists' works. Senior painters such as Gordon Walters saw huge increases, with works that would have sold for between $\$ 1000$ and \$1500 in 1975 achieving $\$ 25,000$ by the mid-80s. ${ }^{23}$ However, McCahon's price increases during this time outpaced those of any other New Zealand artist by a substantial margin. Embarrassed by his sudden wealth, he wrote to McLeavey: "I feel like Scrooge McDuck swimming in a money bin." ${ }^{24}$ As Trevelyan relates:

In 1972, his large Gate III sold for \$4000; six years later, a work of comparable scale, the Northland Panels, was acquired by the National Art Gallery for $\$ 25,000$. In 1985, the gallery paid $\$ 130,000$, the highest price publicly recorded in New Zealand, for Practical Religion. From the late 1970s, in consultation with McCahon and his family, Peter [McLeavey] limited the number of works that could be sold every year so the artist avoided a huge tax bill. In any case, their value was increasing so swiftly it was prudent to retain them. ${ }^{25}$

Into the 1980s, as Peter Simpson writes, “as his mental and physical health diminished, McCahon's recognition and reputation grew." 26 In 1984, as it became apparent that McCahon's poor health meant he was no longer able to paint, Gordon H. Brown's monograph was published and the major exhibition I Will Need Words toured Sydney, Edinburgh and Wellington. McLeavey made several big sales to major Australian galleries in the mid-80s: Simpson notes that "sales of major McCahon paintings for more than $\$ 100,000$ soon became relatively commonplace." 27 Auckland City Art Gallery had been steadily building a collection of McCahon's increasingly valuable work since 1958. Between 1979 and 1990 the collection more than tripled in size with the acquisition of an additional 57 works. ${ }^{28}$ During the same 11-year period, the ACAG staged seven exhibitions featuring McCahon, either as solo presentations or in exhibitions prominently featuring his work, nearly doubling the rate of the previous two decades. ${ }^{29}$ The number of exhibitions featuring McCahon's work continued to dramatically increase through the 1990s: the Gallery's initiative of a dedicated "McCahon Room" meant that solo presentations of his work were almost continuously on display from January 1996 right through into the early $2000 \mathrm{~s}^{30}$ 
McCahon's canonisation is deeply entangled with the Gallery's institutional history. From its emergence as a participant in Auckland's contemporary culture in the 1950s, its development through the 1960s into the most dynamic and forward thinking of New Zealand's public art galleries, and in the increasing focus on collection building during these and subsequent decades, the Gallery's public reputation has mirrored McCahon's in its passage from dynamic emergence to consolidation. This twinned trajectory achieved its logical conclusion when Alexa Johnston's Gates and Journeys was framed as both a tribute to McCahon following his death in 1987 and as an extension of the Gallery's celebration of its 100-year anniversary that same year. As director Christopher Johnstone wrote in the exhibition catalogue: “In recognition of McCahon's stature it was decided that the exhibition would be the last of the Gallery's programme of centenary exhibitions." ${ }^{31}$ Barton remembers:

Auckland Art Gallery had become a gatekeeper. It was moving into the whole neoliberal phase of seeking corporate sponsorship, blockbuster exhibitions, having to serve its stakeholders, funders and so on. The whole mentality of the place was changing ... with power shifting from curators and exhibition makers to sponsorship teams and PR people. $^{32}$

As an emerging curator, Barton had found her way into the institution through what she describes as the "back door" of the research library. Barton was employed as an assistant to Ron Brownson, who was then the librarian, and who ran the library "almost like a counter-institution within the institution," forging an informal network of connections between the Gallery and a diverse community of artists and scholars. From her position in the research library and, as she describes it, "on the fringes" of the institution, Barton developed after McCahon as an explicit challenge to what she saw as the increasing conservatism of the Gallery. ${ }^{33}$ Taking up Brownson's example, she leveraged her own institutional access to create an opening for younger artists engaged in a new mode of practice to show at the Gallery:

OK: we've done McCahon, he's now thoroughly canonised, everyone accepts that was an important thing to do, but now what? And I was deeply aware that there had been this paradigm shift in how artists were working. There was an urgent need for the institution to address in some way their new thinking. ${ }^{34}$

\section{Inside the Trojan Horse}

Barton's goal, in curating after McCahon, was to defy what she perceived as the increasing conservatism of the ACAG, and to acknowledge what was going on in current practice. If, as I have argued, her suggestion of McCahon's influence was at least in part a red herring, what connected the artistic practices on display? How did the interests and motivations of these artists differ from those of previous generations? As Barton's catalogue essay explains, her exhibition centred on a typically postmodern preoccupation with questions around authorial subjectivity-its coherence or lack thereof - as well as an acknowledgement of how language mediates expression. The artists in after McCahon were united by their critical feminist and poststructuralist approaches to representation. They were also, however, engaged in several other discourses that were particularly of their time.

For example, both Julian Dashper and Merylyn Tweedie took advantage of this high profile exhibition opportunity to play with the institutional framing of their work, registering the expansion of strategies of institutional critique during the 1980s. Tweedie (an artist who would 
later be subsumed into the et al. collective) used the titling of her works to identify their targets. In scrubbers or I will need a word processor or thank you marie, 1989, (from the under McCahon series) Tweedie collaged a jumble of photocopied excerpts from Home and Building magazine and dated self-help manuals onto wallpaper. Scrambling communicative efficacy, scrubbers mocked McCahon's famous declaration "I will need words" with the reply "I will need a word processor." Daspher literally played with the institutional framing of his work: he succeeded in persuading ACAG staff to lend him a frame that had previously held a McCahon work in order to exhibit his own. Five of Dashper's smaller works appeared in after McCahon in the frame that had held McCahon's Imprisonment and Reprieve, 1978-79, in Gates and Journeys. ${ }^{35}$ The implication here - that the institution's framing of an artist's work is a form of imprisonment — was of course completely intentional. Both Tweedie and Dashper were acutely aware of their position in both art and institutional history.

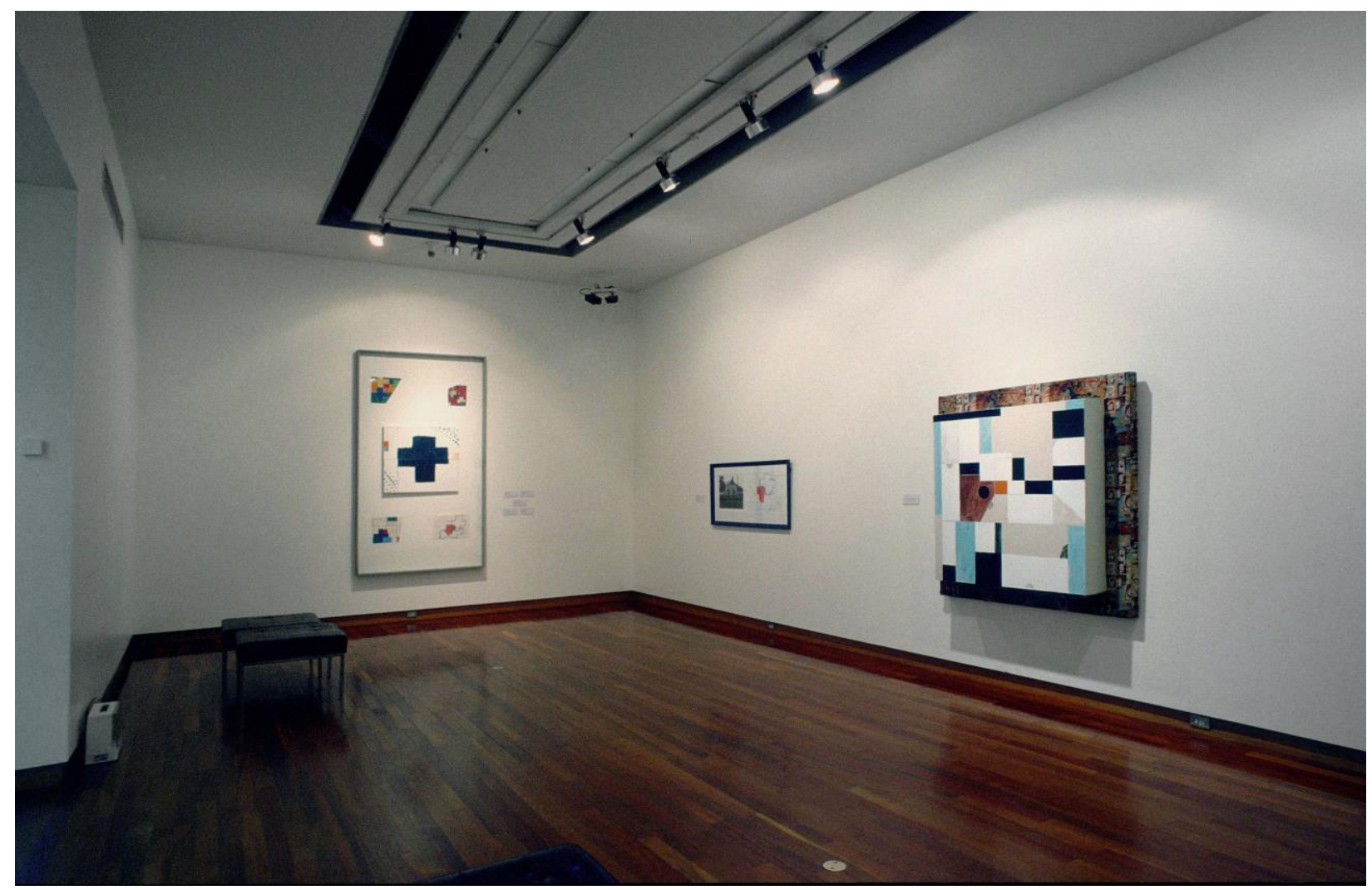

Figure 4. after McCahon: some configurations in recent art, 1989. Auckland City Art Gallery, curated by Christina Barton. Installation image showing works by Julian Dashper. In frame, from top left: Slinter Corner, 1983; Waiting to Go to Rakino Island, 1981; Halley's Comet at Silverdale, 1985; Looking for the Great North Road (Study), 1982; Cass Cartoon, 1986. Centre: Julian Dashper, Cass, 1986. Right: Julian Dashper, Mural for a Contemporary House No. 4, 1988. Image courtesy of Auckland Art Gallery Toi o Tāmaki. 
Two other significant conversations that were also underway in the 1980s were visible in after McCahon. These were, first, the emergence of decolonial politics into the mainstream, and second, the cultural shift reflected in punk and post-punk practices. While in 1989 Barton may have been only partially able to articulate these tendencies in artistic practice, with hindsight they seem crucial to the period.

\section{Decolonial Landscapes}

Looking back, perhaps the most interesting juxtaposition of works in after McCahon was that of Emily Karaka's The Treaty of Waitangi: The Black and White of It, 1986, and Imants Tillers' Hiatus, 1987. Installed facing each other in the exhibition's main room, this pairing staged a conversation between the show's only international artist and Karaka, who as a member of the Ngāi Tai ki Tāmaki iwi is tangata whenua of the Tāmaki Makaurau/Auckland area. Both Karaka and Tillers critically engage settler-colonial histories of landscape representation in their work. Of all the artists in after McCahon, they perhaps also have the closest relationship to McCahon's practice: with Hiatus, Tillers appropriated McCahon's epic Victory Over Death 2, 1970, and Karaka has made no secret of the fact that she considers McCahon a "lifelong mentor." However - and despite Francis Pound's startling assertion that Karaka's relationship to McCahon's work is one of "uncritical acceptance"—both Tillers and Karaka were deeply engaged in the discourses of their time. ${ }^{37}$ To position their work solely, or even primarily, within parameters set by McCahon's practice would be to misunderstand it.

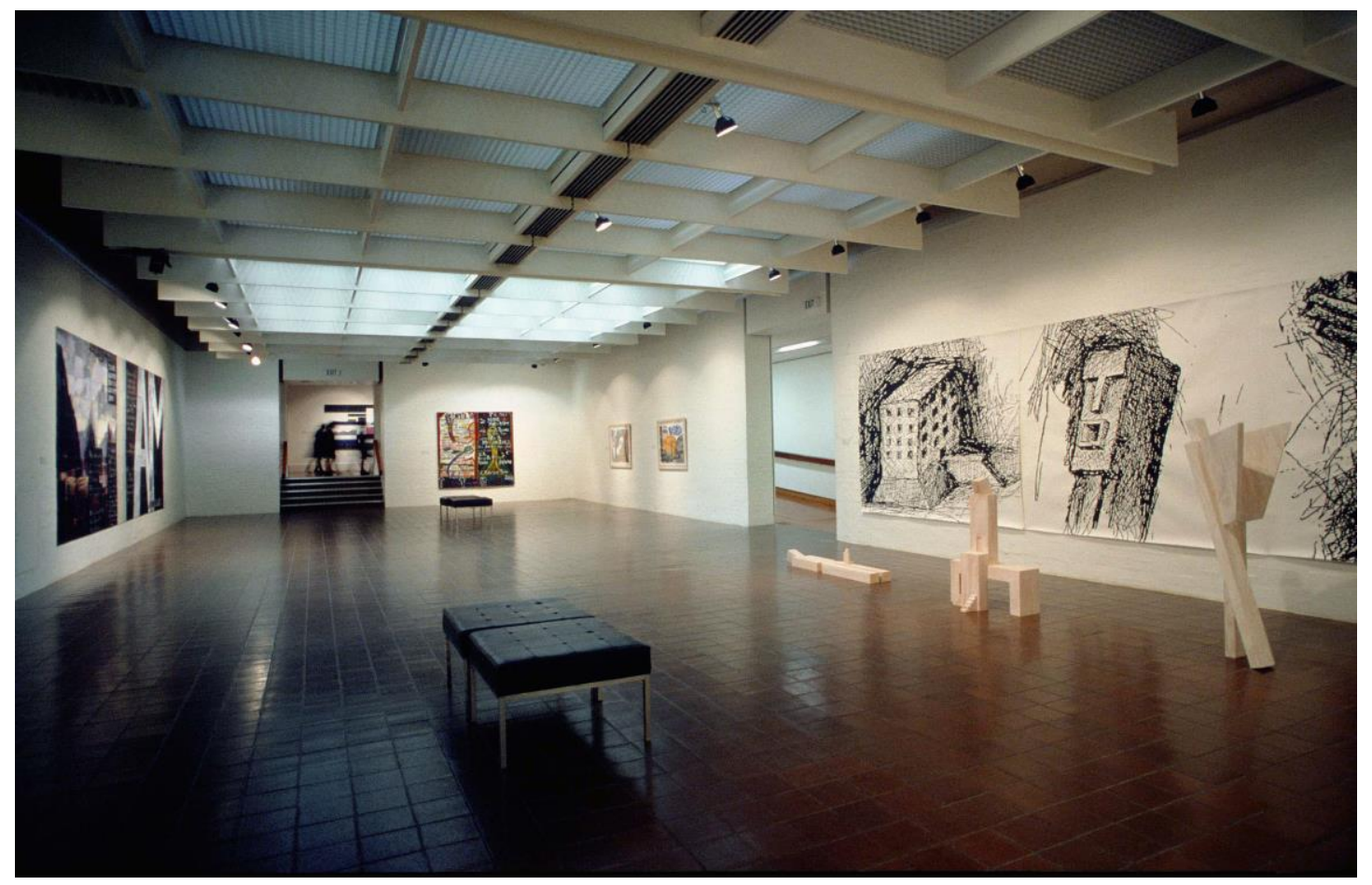

Figure 5. after McCahon: some configurations in recent art, 1989. Auckland City Art Gallery, curated by Christina Barton. Installation image showing, from left: Imants Tillers, Hiatus, 1987; Emily Karaka, The Treaty of Waitangi: The Black and White of It, 1986; Emily Karaka, Creation Series: Mokopuna, 1989; 
Emily Karaka, Creation Series: Te Ra Tu Ao, 1989; Derrick Cherrie, With the Aid of Angels, 1985. Image courtesy of Auckland Art Gallery Toi o Tāmaki.

Tillers' Hiatus is part of the artist's ongoing conceptual painting project The Book of Power, begun in 1981. It is integrated, therefore, into his broader practice of appropriation as well as offering a specific example of his appropriation of McCahon's work. Hiatus combines imagery from McCahon's Victory Over Death 2, 1970, with Eugene von Guerard's Milford Sound, 1877-79. Like the other works that together constitute The Book of Power, it is painted on a modular grid of commercially-produced canvas boards. Ian McLean has described The Book of Power as a "translation machine" in which inherited imagery, produced in the chance meetings of generations of artistic ancestors, is reproduced in a newly hybrid and endlessly reconfigurable iteration. McLean writes:

In subjecting the mimicry in which art originates to complex convergences of difference rather than the simple repetition of sameness - the mimicry of sexual reproduction rather than cloning - The Book of Power is plunged into a mise-en-abyme of displaced origins. ${ }^{38}$

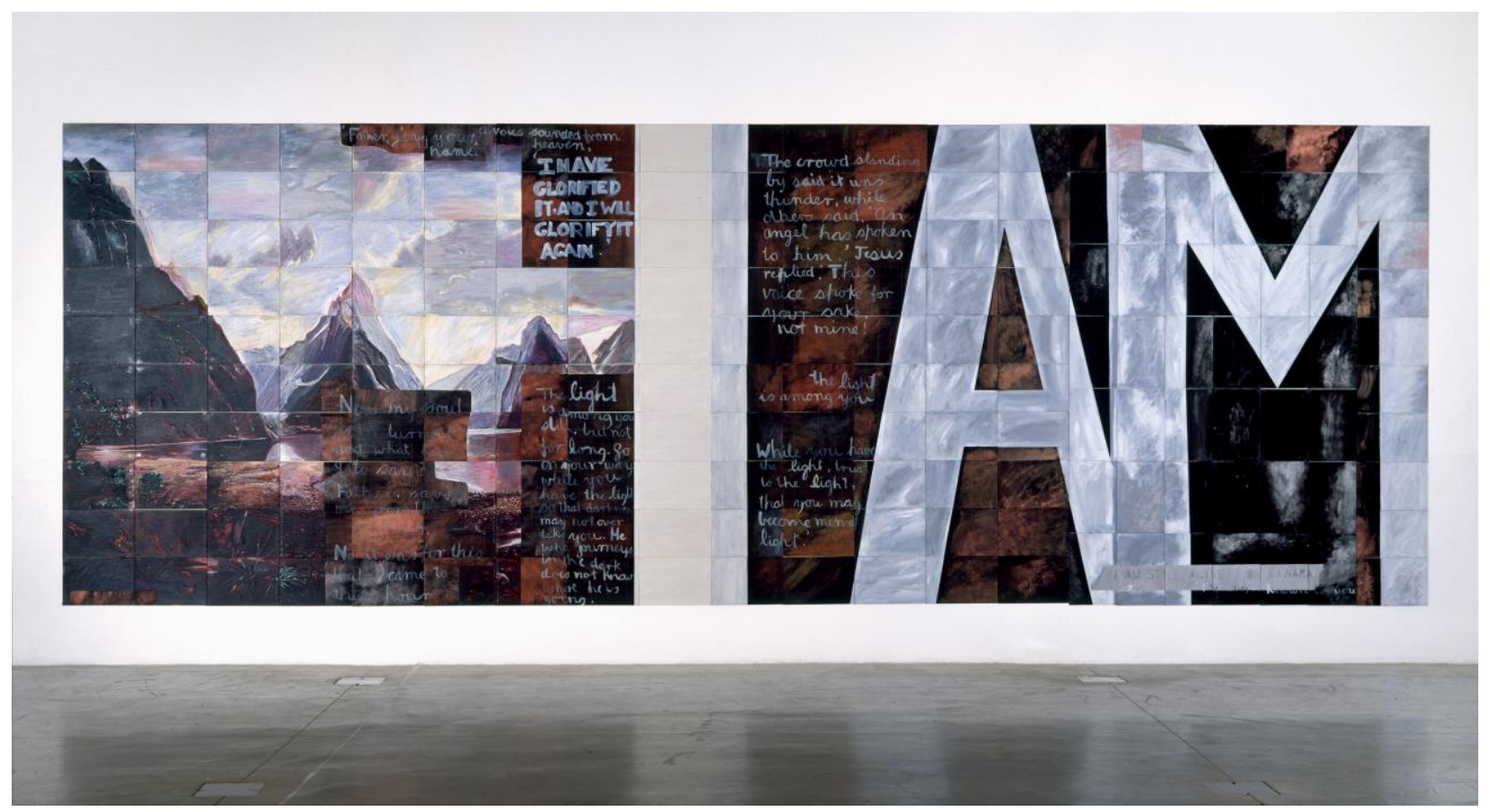

Figure 6. Imants Tillers, Hiatus, 1987. Acrylic, oilstick and gouache on canvas on board, $279.4 \times$ $723.9 \mathrm{~cm}$. Collection of Auckland Art Gallery Toi o Tāmaki, purchased 1988.

Through the 1980s, Tillers was a key player in the Australian postmodern project to reimagine Australia's settler-colonial cultural identity as a copy without an original, a culture of displaced origins. The translations effected in The Book of Power propose that all knowledge is produced in just such an endless process of continuous becoming, of assembling and reassembling fragments. McCahon's oeuvre has been an important model for Tillers. Describing McCahon's work to Jenny Harper in 1998, Tillers could have been talking about his own: "There is a constant tension between the search for meaning, the desire for transcendence and a pervasive, immovable 
skepticism." 39 Barton acknowledges that aspects of McCahon's work were enabling for artists of a younger generation, such as Tillers:

There were traces already there of acts of appropriation, mixing of sign systems, changing relationships to the landscape. The seeds were there in McCahon's work, but there was also a fundamental deeper humanism that no longer held for the generation that I was writing about. ${ }^{40}$

While McCahon's works derive their critical acuity from their position between the polarities of faith and doubt, always subject to the elastic tug of both self-assertion and self-effacement, for Tillers self-effacement and self-assertion are indistinguishable. This is made clear in a series of works - including Hiatus - where Tillers appropriated his own initials from McCahon's paintings. ${ }^{41}$ In Victory Over Death 2, McCahon's thunderous declaration- "I am"-is an assertion of self in which the voice of the artist speaks in the voice of God (no less) to declare his own name. ${ }^{42}$ With tongue in cheek, Tillers resurrected McCahon's statement-which of course was already a quote two times over - as his own authorial mark: the "I" in "I am" now doubles as the first letter in Imants Tillers' signature. ${ }^{43}$

McCahon's passionate and deeply conflicted struggle to articulate his own subjectivity becomes, in Tillers' work, an attack on the very notion of coherent subjectivity on both an individual and a national scale. Hiatus, after all, replicates the masterwork that was controversially gifted to Australia by the New Zealand government in 1978, and returns it home in the form of a copy. ${ }^{44}$ This mischievous coda to a trans-Tasman fracas that had involved much nationalist posturing in the media and many bad jokes made at McCahon's expense, speaks once again to Tillers' postmodern interest in how nationalism is fabricated. However, the way in which Tillers' work engages most deeply with the discourses of the 1980s was not simply in its effort to redefine settlercolonial Australian culture as a copy without an original. It was not only in the way the artist reformulated the provincial mimicry that Terry Smith called 'the provincialism problem' as a feature, rather than a problem, of antipodean identity. ${ }^{45}$ It was in Tillers' dawning awarenesswhich was at least at first poorly expressed - of the sheer scale of Aboriginal dispossession, and of the original violence with which the settler-colonial state was formed. ${ }^{46}$

The decolonial politics at play in both New Zealand and Australia in the 1980s were several orders of magnitude more intensified than that to which McCahon responded when he quoted Matire Kereama in The Lark's Song in $1969 .{ }^{47}$ In New Zealand, the grassroots protest movement that arrested public attention in 1975 when Dame Whina Cooper led the land rights hikoi to Parliament blossomed into the so-called 'Māori Renaissance' of the 1980s. In Australia, the Aboriginal Tent Embassy and the Australian Black Panthers both formed in the early 1970s, at the same time as painters in Papunya were developing a new way of working. By the early 1980s, Papunya Tula paintings were appearing in high-profile international contemporary art exhibitions, and by the late 1980s a new generation of extraordinary First Nations artists like Michael Parekowhai, Peter Robinson, Tracey Moffatt and Gordon Bennett were graduating from the art schools.

In this context, the notion of settler-colonial culture as a copy without an original unintentionally articulates the extent to which many citizens of settler-colonial states remained wilfully blind to their actual cultural origins in genocidal violence. Barton's decision to juxtapose Tillers' and

Journal of New Zealand Studies NS31 (2020), $72-94$ https://doi.org/10.26686/jnzs.v0iNS31.6679 
Karaka's works, therefore, seems politically pointed. Like other Māori artists who came to prominence in the 1980s, Karaka's practice is intimately connected to her activism on behalf of Tangata Whenua. ${ }^{48}$ Karaka and McCahon both conceived of landscape in an expanded sense that also incorporates language. However, with paintings like The Treaty of Waitangi: The Black and White of It, Karaka explicitly targets the connection between legal language, land rights, whakapapa, and the material conditions of the artist's capacity to speak. Francis Pound was both poorly informed and insulting when he wrote that Karaka's "manner of inscribing a Maori voice on the land" should be attributed to McCahon: "It was McCahon who showed her how this might be done." ${ }^{49}$ As Sandy Adsett, Witi Ihimaera and Cliff Whiting patiently explained in 1996:

Perhaps because Maori of the past have always had an intimate relationship with the land,... [they] could not distance themselves sufficiently to be able to define-as Western traditions of landscape painting did - what that relationship was. It just was. It just is.... Today, representation of the land is a major theme of Maori artists and Papatuanuku has become a principal visual concept. This is not to be wondered at. The interposing by pakeha of themselves between Maori and the land, by threatening that earlier intimate relationship, has inspired Maori artists not only to actively reaffirm the place of the land in our culture but also to use our renderings of Papatuanuku as protest. ${ }^{50}$

As a Pakeha curator, Barton remembers having only a vague awareness of decolonial politics when she put together after McCahon. From her perspective, Karaka's use of the conflicting Māori and English translations of the Treaty of Waitangi in her painting resonated with feminist and poststructuralist claims about the gaps and elisions that exist between words and their objects, the slippages in translation that demonstrate language's wayward mediations of truth. However, she also recognised that Karaka's activism presented a different approach to these efforts to dismantle existing power structures:

To inscribe [her painting] with this sort of legalese that actually engages the whole question of ownership and sovereignty, seemed to me to be . . . the answer to McCahon's application of language over the landscape. It was the unspoken other side that needed to be said. I thought that work was incredibly important. ${ }^{51}$

Karaka's paintings are often described as neoexpressionist. Her impassioned mark-making and clearly stated politics convey an authenticity and integrity that is fundamentally at odds with postmodern scepticism and equivocation. However, when recognised as protest statements that are cognisant of the power of language - legal, verbal and pictorial - to shape reality, it becomes clear that Karaka's works strategically deploy the expressionist mark in the service of specific political goals. They are both critical and emotional, demonstrating how politics is personal, how history and law are inscribed in the body.

Tillers and Karaka were engaged in a conversation about settler-colonial identity, decolonial politics and our relationships to landscape and place. ${ }^{52}$ During the last, inactive, years of McCahon's life, this conversation had developed - largely due to figures like Tillers and Karakainto a discussion substantially different to the one he had participated in. To read their work in terms predetermined by McCahon's practice, as Francis Pound did with Karaka, is to ignore this difference and fail to recognise the contribution of these artists. In the simplest terms, then, Barton's exhibition attempted to garner recognition for the work of her generation. Of course, it is 
deeply ironic that she needed to invoke McCahon's name to do so, and indicative of the extent to which her intervention was necessary.

\section{Something Nothing: Punk and Postmodern Painting}

after McCahon recognised and articulated a developing postmodern attitude towards practices of mark-making and representation that was critical of canonisation and conventional authorship. Barton's approach reflects the extent to which scholarly discourse at this time was dominated by the work of writers associated with October magazine. However, she didn't acknowledge the connections - which are more easily visible with the benefit of hindsight - between contemporary visual art and a broader cultural shift represented by punk and post-punk practices. Punk's influence can be seen in the raw, scrappy aesthetic of postmodern painting; more broadly, punk's critique of the hippie counterculture contributed to a change in what it meant to be avant garde in the 1980s. This became increasingly obvious in the early 1990s with the influence of Los Angeles artists like Mike Kelley and the grunge-oriented work of artists like those involved in Auckland's Teststrip collective. ${ }^{53}$

By 1989, the international revival of studio-based painting practice was firmly established. ${ }^{54}$ Neoexpressionist mark-making, and a kind of subcultural urban primitivism privileging the raw, direct, and gestural had been causing despair amongst the October critics since the early 1980s. ${ }^{55}$ However, when writers like Benjamin Buchloh characterised this renewed interest in painting as inherently neoconservative and market driven, he dramatically oversimplified a tendency that played out across a diverse range of artistic practices. As Isabelle Graw has explained, postmodern painters were in many cases deploying the critical strategies of conceptual art in their work. While acknowledging that from almost any angle Julian Schnabel's "bare-chested self-staging" pandered perfectly to "the art world's desire for the violent bravado of a "celebrity painter," Graw describes how Martin Kippenberger, for example, used paint squeezed direct from the tube to create works that were:

exaggerated signs for an immediacy that does not pose as authentic utterance or expression. They thus stand less for the impulsive gestures of an artist than for his or her interest in a pictorial vocabulary that creates the impression of "immediacy" in order to demonstrate the fact that it is mediate. ${ }^{56}$

Here, Graw could equally be describing the work of Julian Dashper (who also used paint squeezed directly from the tube in works like Bridge Under Construction, Dome Valley, 1987) or John Reynolds's Armature for a Headland, 1985. As is evident from Reynolds's career-long preoccupation with sign systems, his roughly articulated line with its hesitations and flaws is less an autographic mark than an insistent reference to the materiality of the artwork and its continual mediation of these signs of expressivity. 


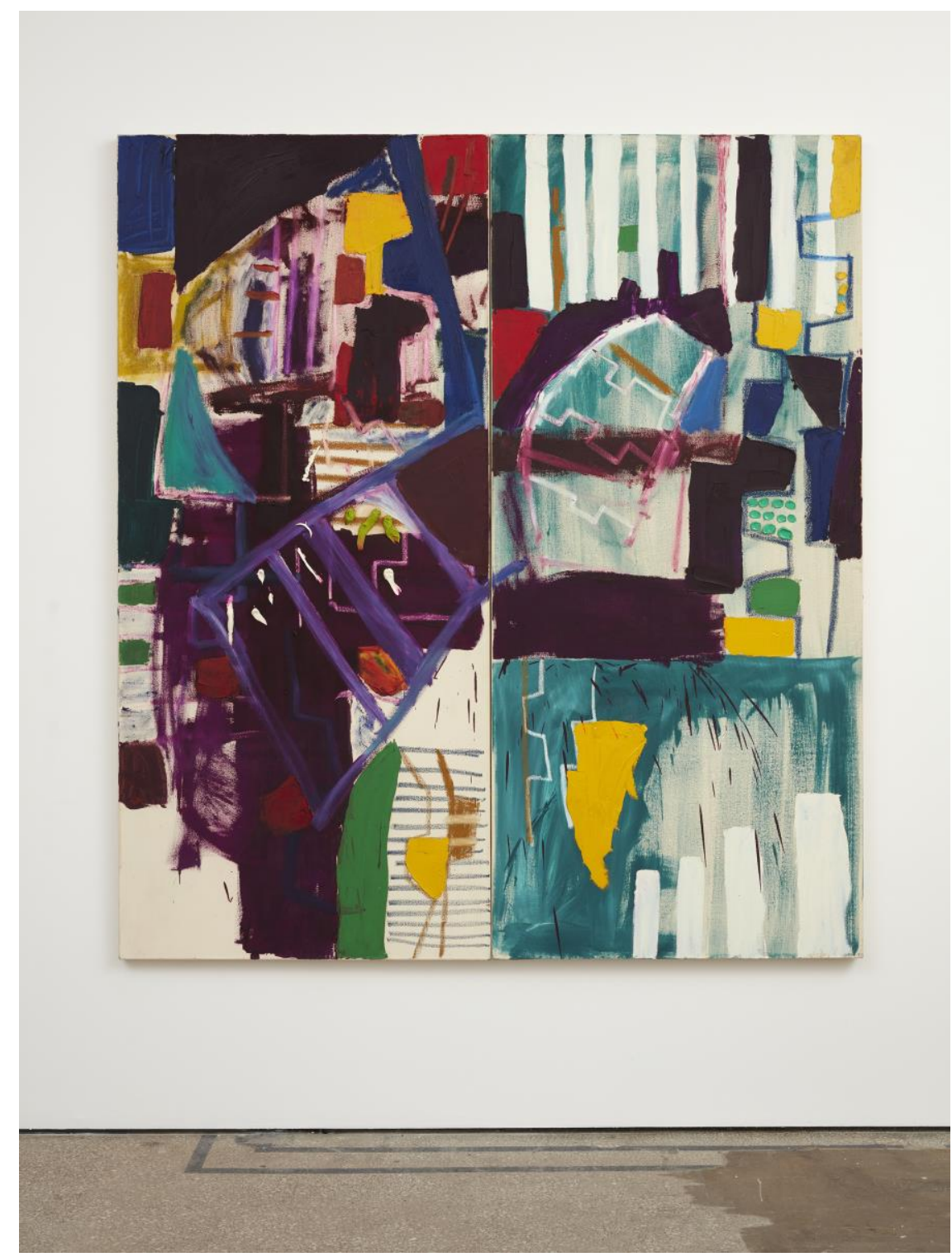

Figure 7. Julian Dashper, Bridge Under Construction, Dome Valley, 1987. Oil and conté on canvas, diptych, total dimensions $201 \times 181 \mathrm{~cm}$. Image courtesy of the Julian Dashper Estate.

Barton strategically invoked the name of McCahon in order to open the Auckland City Art Gallery to the practices of a younger generation, to "acknowledge," as she put it, "that there might have been a radical break." ${ }^{57}$ So how did this difference actually manifest? After all, as Andrew Clifford pointed out in 2008, John Reynolds' body of work is marked by his "trademark scrawl," and this is perhaps not so different to the way in which McCahon's handwriting is also "everywhere and immediately recognisable." 58 As Barton also acknowledged in her catalogue essay, McCahon never simply used the painterly mark as a sign of self in the manner of an abstract expressionist; he constructed a language out of conventional signs and symbols. However, Barton argued convincingly that McCahon's underlying humanism provided the major point of distinction from the work of her own generation. For McCahon, she explained, "communicability itself was never doubted; nor was the belief that his was a representative response to a universal human 
condition." 59 I would add that the facts of McCahon's canonisation lent additional autographic weight to that handwriting that is "everywhere and immediately recognisable." McCahon's own artistic and existential doubts served, ultimately, to reinforce his prophetic status. The struggle that plays out across the surface of his paintings has become material evidence of Gordon H. Brown's tragic narrative of his life: the stuff of a blockbuster.

The raw directness of the painterly mark in McCahon's work was, in 1989, a sign of his blue-chip credentials as artistic visionary. The roughly executed works of younger artists of the 1980s were cognisant of this: the market was a fact and factor in the practices of these artists in a way that it simply hadn't been for McCahon. However, in addition to becoming a sign of highly marketable artistic melodrama, slapdash execution also aligned with the energy and irony of post-punk artistic and popular culture. Graeme Cornwell's mixed-media wall works channel punk's high-energy low-skill methodology into Tatlinesque assemblages that take lazy collage to new heights. In Something Nothing, 1988, instead of fixing pieces of found cardboard to the surface of the work Cornwell attached entire uncut boxes, adorning the whole Heath Robinson construction with nonsense words: LA-LA, DO-BE, HA-HA, YA-YA. Mocking the high seriousness of McCahon's existential conundrums, the light emerging from the darkness in Cornwell's Something Nothing emits only jovial and nihilistic Dada-ist pronouncements.

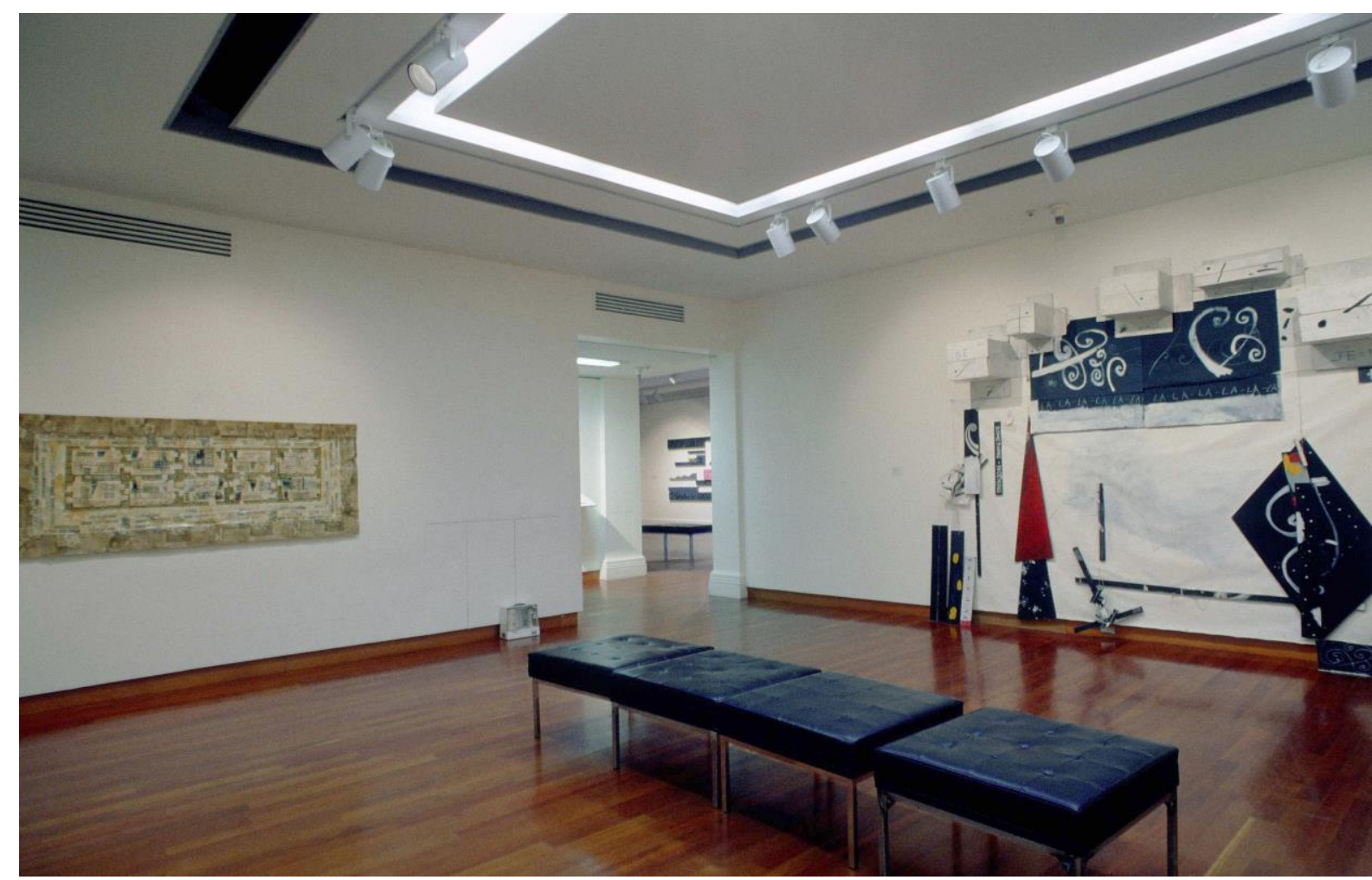

Figure 8. after McCahon: some configurations in recent art, 1989. Auckland City Art Gallery, curated by Christina Barton. Installation image showing, from left: Merylyn Tweedie, scrubbers or I will need a word processor or thank you marie (from the under McCahon series), 1989; Graeme Cornwell, Something Nothing, 1988. Image courtesy of Auckland Art Gallery Toi o Tāmaki. 
All of the works in after McCahon in some way register the dissolution of their own coherence or the degradation of their imagery. Many, like Cornwell's and Barbara Strathdee's, are literally in pieces. Strathdee's The Meeting on the Beach, 1988, is a landscape painting atomised into distinct panels, each bearing painterly brushstrokes whose function has been reduced to the provision of surface texture. A detail appropriated from a nineteenth-century Charles Heaphy watercolourhere appearing as an enlarged and degraded reproduction four generations distant from the original-is overlaid on lolly-pink brushstrokes in the central panel. ${ }^{60}$ Paintings disassembled into their component parts, these works demonstrate their representational mediation. Charles Heaphy's representation of colonial encounter seems to float through Strathdee's flotilla of painted fragments, unanchored, and equivalent in value to her panels of decorative-expressive brushstrokes. John Reynolds' hastily scrawled Armature for a Headland, 1988, is similarly "a landscape of sorts" that serves to open "the fertile area between mark-making and the meanings we ascribe to it." 61

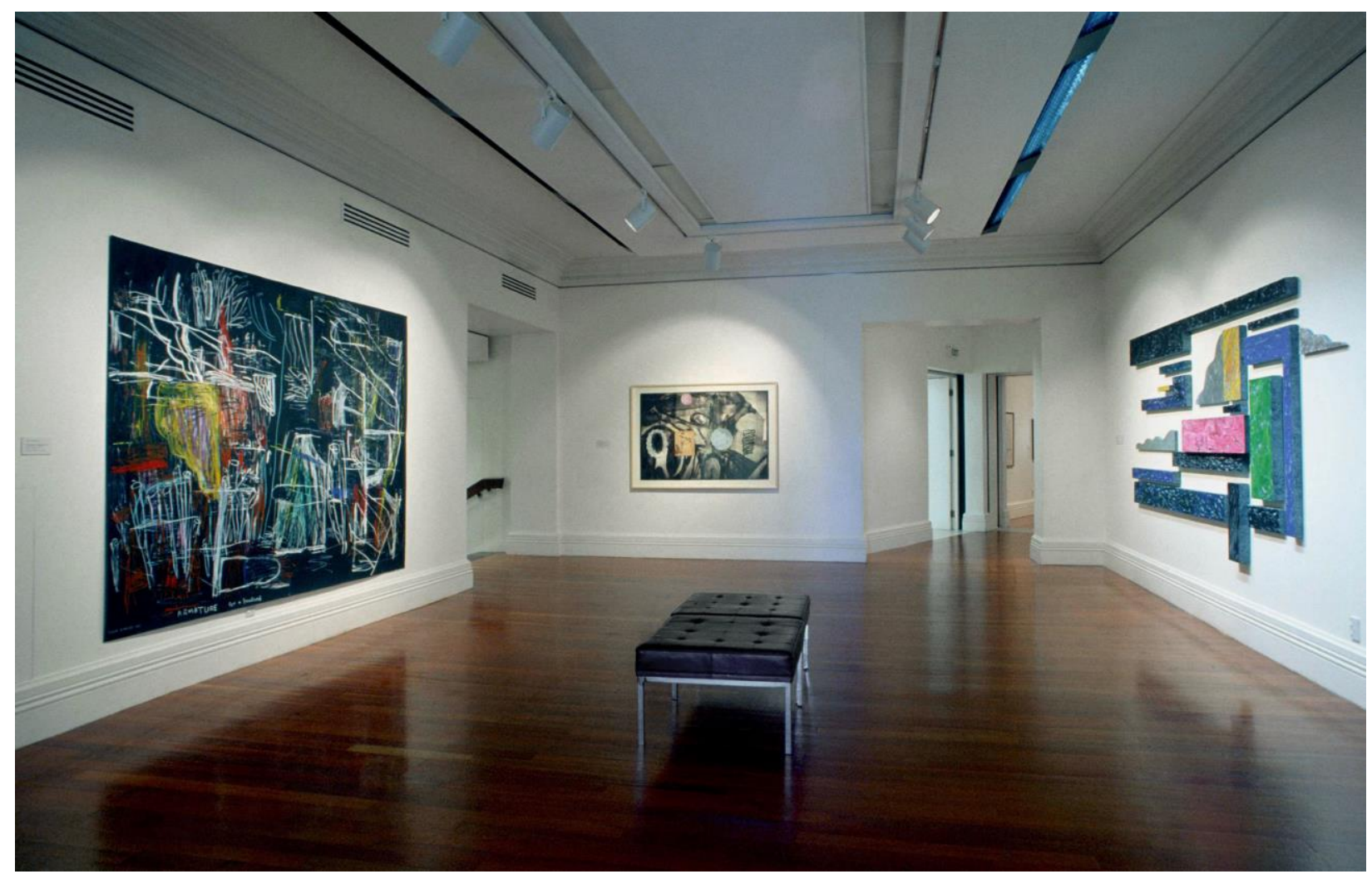

Figure 9. after McCahon: some configurations in recent art, 1989. Auckland City Art Gallery, curated by Christina Barton. Installation image showing, from left: John Reynolds, Armature for a Headland, 1985; John Reynolds, Bouquet for Colin McCahon, 1987-89; Barbara Strathdee, The Meeting on the Beach, 1988. Image courtesy of Auckland Art Gallery Toi o Tāmaki. 
It is not incidental that Reynolds designed several record covers for the post-punk band Blam Blam Blam, whose 1981 single, There is No Depression in New Zealand, rose into the top 20 amidst the violent generation-defining protests of that year's Springbok Tour. ${ }^{62}$ The song's upbeat, driving rhythm is rendered ironic by the biting sarcasm of its description of Muldoon-era conservatism:

There is no depression in New Zealand

There are no teeth in our heads

There is no depression in New Zealand

We sleep in a well made bed. ${ }^{63}$

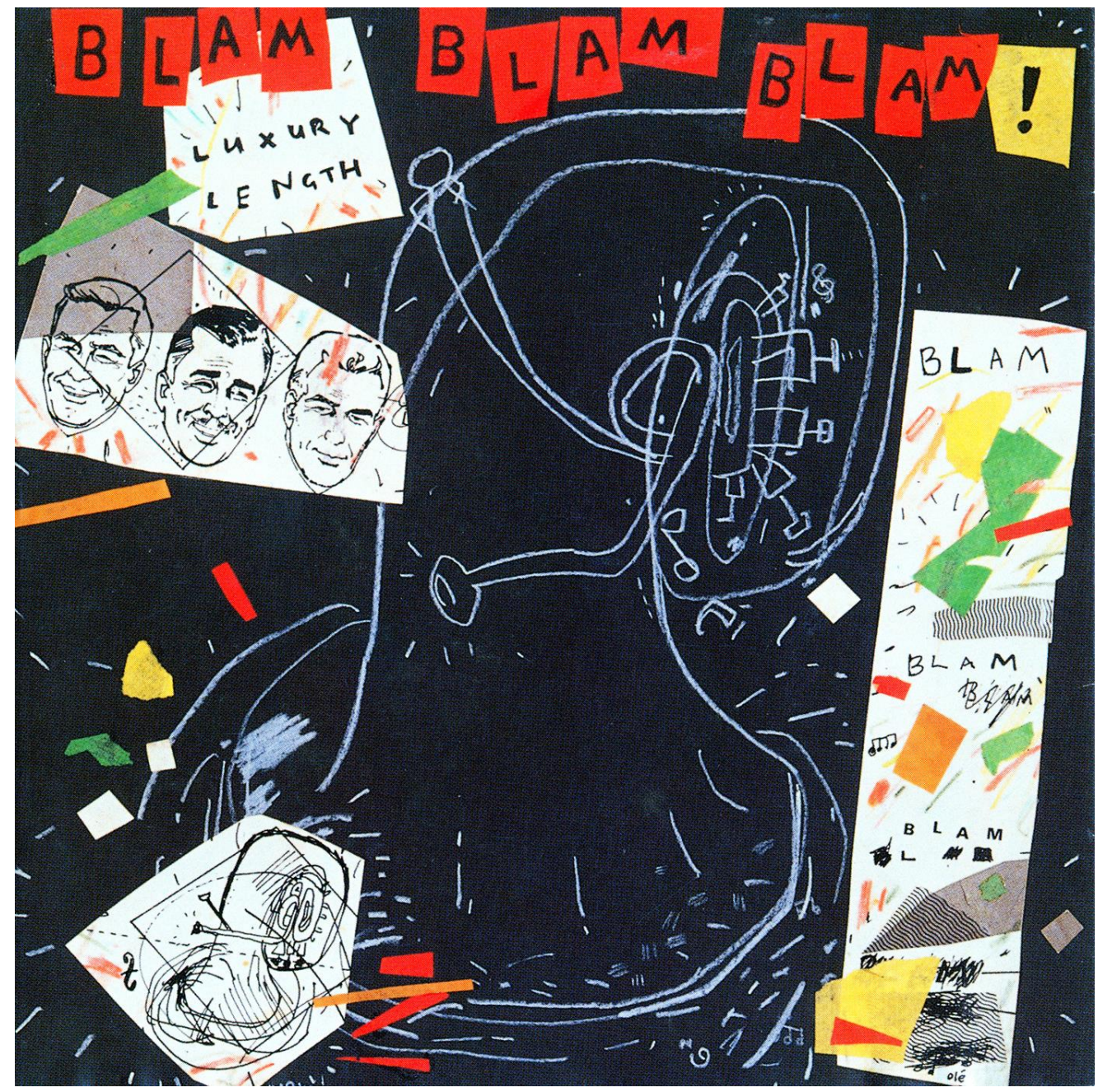

Figure 10. Blam Blam Blam, Luxury Length. With Mark Bell, Tim Mahon and Don McGlashan, recorded May 1982 at Harlequin Studios, Auckland, produced by Blam Blam Blam and Paul Streekstra, record cover by John Reynolds. Propeller Records REV 204, 1982. Image courtesy of Blam Blam Blam and Propeller Records. 
Chris McAuliffe and Wystan Curnow have both described punk's influence on visual art in New Zealand and Australia from the late 1970s. ${ }^{64}$ For McAuliffe, the crossover between art and music cultures informed what Paul Taylor called the "second degree," postmodernism's self-conscious dislocation from (and perpetual orbit around) the idea of source or origin. ${ }^{65} \mathrm{He}$ describes how the Melbourne scene centred on St Kilda's Crystal Ballroom enabled musicians and visual artists to together explore a new, highly self-aware approach to avant-garde bohemianism that fused authenticity and artifice:

The cross-over between art and punk was built on a mutual recognition of the highly coded nature of art and mass culture alike. While rock still clung to a romantic myth of bohemia, punk encouraged artists to become more self-conscious of the conventions of that myth. Young artists sought to establish their difference from the mainstream even as they became increasingly aware of the artificiality of the gesture. ${ }^{66}$

Punk rejected the romanticism of the hippie counterculture's efforts to either drop out of society or rebuild it in communes or organic food co-ops. As McAuliffe notes, punk also recognised how the heroic posturing of the rock star is similarly romantic and, of course, highly marketable. In the same way that Graeme Cornwell's Something Nothing parodies artistic angst, punk musicians channelled their anti-establishment energy into aggressively low-quality performances of the rock star cliché. It is, finally, this note of savage irony, born of artists' frustrated awareness of their own unavoidable complicity with the market structures that dominated art practice in the 1980s, that differentiates after McCahon from McCahon.

Young artists of the 1980s were acutely aware of the market as a context for the reception of their work and a core factor in institutional processes of canonisation. To acknowledge this, however, is not to agree with the too-common perception of art of the 1980s as anti-intellectual and market oriented, a neoconservative spectacle. Artists developed a variety of responses to the newly powerful market forces that endowed artists like McCahon with "unquestionable" authority. ${ }^{67}$ French poststructuralist thought, filtered through the work of US, Australian and New Zealand art writers, offered a theoretical framework with which to deconstruct inherited notions about authorship and authority. Emerging into mainstream consciousness, decolonial politics began to profoundly shift the cultural and legal foundations of settler-colonial conceptions of identity. And punk introduced a means for artists to acknowledge their unavoidable complicity with, but simultaneously their rage at, late capitalist society. The "expressive" gestures of the artists in after McCahon, dripping with postmodern irony, were made in the knowledge that theirs was a highly coded and compromised activity. This was of course due in part to the example of McCahon's canonisation: the fetishisation of his handwriting and the institutional authority amplifying his voice. Barton's exhibition was a critical intervention into the ACAG exhibition programme which acknowledged the work of her generation and presented an argument about their difference from earlier generations of artists. By invoking the name of the artist immortalised in Gates and Journeys, she opened a path into the institution but also, through her subterfuge, demonstrated the extent to which the intervention was necessary. 
I gratefully acknowledge the assistance of Christina Barton, who generously shared her memories and critical insights with me as I developed this paper. Thanks also to Caroline McBride, E. H. McCormick Research Library, Auckland Art Gallery Toi o Tāmaki and Rex Butler for very helpfully making several key resources available, and to Geoffrey Heath and Jennifer French at Auckland Art Gallery Toi o Tāmaki for assistance with images.

${ }^{1}$ Auckland City Art Gallery changed its name to Auckland Art Gallery Toi o Tāmaki in 1996.

${ }^{2}$ Christopher Johnstone, "Foreword," in Colin McCahon: Gates and Journeys, ed. Alexa Johnston, Gordon H. Brown, Wystan Curnow, and Tony Green (Auckland: Auckland City Art Gallery, 1988), 9. ${ }^{3}$ Available in Laurence Simmons, The Image Always Has the Last Word: On Contemporary New Zealand Painting and Photography (Palmerston North: Dunmore Press, 2002), 52-67.

${ }^{4}$ Barton also recalls that attending Sydney Biennales during this period was an important source of information. Barton and Michael Stevenson studied together in Roger Horrocks's class in the Film Studies department of Auckland University. Stevenson remembers that it was through the analysis of filmic images that "you would then go on and read something like Barthes. This was the entry point, through film." Christina Barton, interview with the author, 16 July 2020; Michael Stevenson, interview with the author, 15 November 2013.

${ }^{5}$ Johnstone, "Preface," in after McCahon: some configurations in recent art, ed. Christina Barton (Auckland: Auckland City Art Gallery, 1989), 5. Emphasis added.

6 Johnstone, "Preface," 5.

${ }^{7}$ Christina Barton, "After-Words: Conversation around McCahon," in after McCahon: some configurations in recent art, (Auckland: Auckland City Art Gallery, 1989), 7-17.

${ }^{8}$ Barton, interview with the author, 16 July 2020.

${ }^{9}$ Michael Stevenson, quoted in Gregory O'Brien, "Michael Stevenson: Putting the Fun into Fundamentalism," in Lands \& Deeds: Profiles of Contemporary New Zealand Painters (Auckland: Godwit, 1996), 135.

${ }^{10}$ Gordon H. Brown, Colin McCahon: Artist (Wellington: A. H. \& A. W. Reed, 1984), 3.

${ }^{11}$ Francis Pound, "In the Wake of McCahon: A Commentary on after McCahon," Art New Zealand 52 (1989): 79-83.

${ }^{12}$ Francis Pound, New Image: Aspects of Recent New Zealand Art (Auckland: Auckland City Art Gallery, 1983). The New Image artists were the generation that taught some of the artists in after McCahon: Dick Frizzell, for example, taught both Michael Stevenson and Julian Dashper at Elam School of Fine Arts. ${ }^{13}$ Pound, "In the Wake of McCahon," 82.

${ }^{14}$ Stevenson is no longer religious, but he was deeply involved in a fairly extreme form of Pentecostal Christianity at the time. In contrast to McCahon's millenarianism, which was always directed towards the realisation of the promised land in the here and now, Pentecostalism is animated by its fervent expectation of a temporal rupture of world-ending proportions. For a discussion of Stevenson's paintings as an articulation of Pentecostalism's end-times orientation, see Anna Parlane, "Postmodern Pentecostalism: Apocalyptic Time in the Paintings of Michael Stevenson," Burlington Contemporary no. 3 (June 2020): http://contemporary.burlington.org.uk/journal/journal/postmodern-pentecostalism-apocalyptic-time-inthe-paintings-of-michael-stevenson.

${ }^{15}$ Peter Simpson, Colin McCahon: There Is Only One Direction, Vol. 1 1919-1959 (Auckland: Auckland University Press, 2019), 196.

${ }^{16}$ Jill Trevelyan, Peter McLeavey: The Life and Times of a New Zealand Art Dealer (Wellington: Te Papa Press, 2013), 43-44.

${ }^{17}$ McCahon exhibited at Helen Hitchings Gallery, which opened in Wellington in 1949; Peter Webb's Argus House, Gallery which opened in Auckland in 1957; and Andre and Barbara Brooke's Gallery 91, which opened in Christchurch in 1959. Trevelyan, Peter McLeavey, 46. 
${ }^{18}$ Trevelyan, Peter McLeavey, 47.

${ }^{19}$ Peter Webb, whose Argus House Gallery was Auckland's first commercial gallery, was McCahon's assistant at ACAG and also his neighbour in Titirangi. Simpson, There Is Only One Direction, 215, 280.

${ }^{20}$ Trevelyan, Peter McLeavey, 49, 59.

${ }^{21}$ Trevelyan, Peter McLeavey, 58.

${ }^{22}$ McCahon resigned from teaching at Elam in January 1971. Peter Simpson, Colin McCahon: Is This the Promised Land? Vol. 2 1960-1987 (Auckland: Auckland University Press, 2020), 143.

${ }^{23}$ Trevelyan, Peter McLeavey, 304.

${ }^{24}$ Colin McCahon, letter to Peter McLeavey, 13 June 1978, quoted in Simpson, Is This the Promised Land, 288.

${ }^{25}$ Trevelyan, Peter McLeavey, 304.

${ }^{26}$ Simpson, Is This the Promised Land, 347.

${ }^{27}$ Simpson, Is This the Promised Land, 347.

${ }^{28}$ This data comes from the Colin McCahon online catalogue published by The Colin McCahon Research and Publication Trust at http://www.mccahon.co.nz/.

${ }^{29}$ There were eight shows held over the preceding 23 years. These numbers are taken from Auckland Art Gallery's exhibition history, and represent a simple count of the number of exhibitions featuring McCahon's name in their title. Of course, his work would also have appeared in numerous additional group and thematic exhibitions at the gallery during this period. See https://rfacdn.nz/artgallery/assets/media/auckland-art-gallery-exhibition-history.pdf.

${ }^{30}$ There were 32 exhibitions featuring McCahon's name in the title held at Auckland Art Gallery between 1990 and 2011, when the gallery closed for a major building project.

31 Johnstone, "Foreword," 9.

${ }^{32}$ Barton, interview with the author, 16 July 2020.

${ }^{33}$ Barton, interview with the author, 16 July 2020.

${ }^{34}$ Barton, interview with the author, 16 July 2020.

35 The provenance of the frame was not, however, revealed to exhibition viewers (Barton, interview with the author, 16 July 2020). McCahon described Imprisonment and Reprieve as "the Blake inspired 'Satanic Mills' painting" (Colin McCahon, quoted in Simpson, Is This the Promised Land? 323).

36 "About," Emily Karaka: Artist, https://www.emilykaraka.com/about.

${ }^{37}$ Pound, "In the Wake of McCahon," 80.

${ }^{38}$ Ian McLean, "The Metaphysics of Mimicry: Why Imants Tillers Appropriates Aboriginal Art," in Imants Tillers: Journey to Nowhere, ed. Elita Ansone and Marni Williams (Sydney: Power Publications, 2018), 165.

${ }^{39}$ Imants Tillers, quoted in Graham Coulter-Smith, The Postmodern Art of Imants Tillers: Appropriation En Abyme, 1971-2001 (Southampton and London: Fine Art Research Centre, Southampton Institute, and Paul Holberton Publishing, 2002), 146.

${ }^{40}$ Barton, interview with the author, 16 July 2020.

${ }^{41}$ For example, Tillers's The Letter I and The Letter T, both 1988, and The Bridge of Reversible Destiny, 1990, appropriate the letters I and T from McCahon's The days and nights in the wilderness showing the constant flow of light passing through the wall of death, 1971, and St. Mathew: lightning, 1979. CoulterSmith, The Postmodern Art of Imants Tillers, 168.

42 "Moses said to God, 'Suppose I go to the Israelites and say to them, "The God of your fathers has sent me to you," and they ask me, "What is his name?" Then what shall I tell them?' God said to Moses, 'I AM who I AM. This is what you are to say to the Israelites: "I AM has sent me to you."” Exodus 3:1314, New International Version.

${ }^{43}$ The work's games with repetition are too many to mention; however, the Biblical quote in McCahon's painting "I have glorified it and I will glorify it again" takes on new levels of irony in its reproduction, as does the repetition already in McCahon's title: Victory Over Death 2 not only anticipates its own resurrection, but as the numeral "2" indicates it was already a sequel in its original iteration.

Journal of New Zealand Studies NS31 (2020), $72-94$ https://doi.org/10.26686/jnzs.v0iNS31.6679 
${ }^{44}$ McCahon's Victory Over Death 2 attracted critical comment in both the Australian and New Zealand press at the time of the gift. See for example "NZ Arts Head Defends Painting," Canberra Times, 18 March 1978, 8. Tillers's Hiatus was acquired by the ACAG in 1988.

45 Terry Smith, "The Provincialism Problem," Artforum 13, no. 1 (September 1974): 54-59; Imants Tillers, "Locality Fails," Art \& Text 6 (Winter 1982): 51-60.

${ }^{46}$ A controversy erupted in the late 1980s around Tillers's unauthorised appropriation of Michael Nelson Jagamara's painting Five Stories, 1984, in his The Nine Shots, 1985. Gordon Bennett responded with the whip-smart The Nine Ricochets, 1991. For an initial response, see Juan Davila, "Aboriginality: A Lugubrious Game?" Art \& Text 23/24 (March-May 1987): 53-58. For an extended commentary, see Ian McLean, "9 Shots 5 Stories: Imants Tillers and Indigenous Difference, part 1," Art Monthly Australia 228 (April 2010): 13-16; and Ian McLean, "9 Shots 5 Stories: Imants Tillers and Indigenous Difference, part 2," Art Monthly Australia 229 (May 2010): 12-16.

${ }^{47}$ McCahon's The Lark's Song, 1969, was one of several works made that year which quoted passages from Matire Kereama, The Tail of the Fish: Maori Memories of the Far North (Auckland: Oswald-Sealy, 1968).

${ }^{48}$ Artists such as Kura te Waru Rewiri, Shona Repira Davies, Diane Prince and Robyn Kahukiwa. Karaka's activism led, in the early 1990s, to a role representing her iwi in legal negotiations around Treaty claims. See Sandy Adsett, Witi Ihimaera, and Cliff Whiting, eds. Mataora: The Living Face: Contemporary Maori Art (Auckland: David Bateman, 1996), 88, and Brook Andrew, ed., NIRIN (Sydney: Biennale of Sydney, 2020), 150.

${ }^{49}$ Pound, "In the Wake of McCahon," 80.

${ }^{50}$ Adsett, Ihimaera and Whiting, Mataora, 86. It is also worth acknowledging, as Adsett, Ihimaera and Whiting also do, a widespread emphasis on the use of Te Reo in art of the 1980s-90s. See Mataora, 90 91, and see for example Shona Rapira Davies and Robyn Kahukiwa, Whakamamae (Wellington:

Wellington City Art Gallery, 1988).

${ }^{51}$ Barton, interview with the author, 16 July 2020.

${ }^{52}$ As Barton pointed out to me, Barbara Strathdee's The Meeting on the Beach, 1988, also contributed to this conversation. By quoting Charles Heaphy's Committee at Patapata, Strathdee acknowledged New Zealand's colonial landscape painting tradition while also specifically referencing a financial transaction that removed Māori from their land. Such transactions were what allowed McCahon to perceive the land as empty.

${ }^{53}$ In New Zealand, the connection between painting and punk or post-punk music is most evident in Bill Hammond's manic, Jim Nutt-influenced, pre-Buller work of the mid to late 1980s. See Chris Knox, "Prepare for Indigestion: Random Regurgitation on Rock and Pop Music in Early Bill Hammond," in Bill Hammond: Jingle Jangle Morning, ed. Jennifer Hay, (Christchurch: Christchurch Art Gallery, 2007), 4249. While in 1989 Barton didn't recognise punk's influence on the work in after McCahon, it was pointed out to her in 1993 when Jim and Mary Barr put on an exhibition titled after (after) McCahon:

Refashioning the New in their offices in Wellington. This was shortly after Barton had arrived in the city as the new Curator of Contemporary New Zealand Art at the newly established Museum of New Zealand Te Papa Tongarewa (previously the National Art Gallery and National Museum), and the Barrs' initiative was clearly intended as a comment on Barton's own institutionalisation. Their show presented works by several members of Teststrip, such as Giovanni Intra, Daniel Malone and P Mule, others like Julian Dashper who had also shown in after McCahon, and works like Michael Parekowhai's The Indefinite Article, 1990, that Barton notes would certainly have been included in her exhibition if it had been made two years earlier (Barton, interview with the author, 16 July 2020). The single-page catalogue for after (after) McCahon is held in the E. H. McCormick Research Library, Auckland Art Gallery Toi o Tāmaki. ${ }^{54}$ This revival was signalled from the late 1970s by exhibitions like Marcia Tucker's Bad Painting, 1978, at New York's New Museum, which was followed by A New Spirit in Painting at London's Royal Academy in 1981 and Zeitgeist at Berlin's Martin-Gropius-Bau in 1982. Ron Radford's Wild Visionary 
Spectral: New German Art, 1986, at the Art Gallery of South Australia, built on earlier exhibitions of the new European painting at the Sydney Biennale, and toured to both Perth and Wellington.

${ }^{55}$ Benjamin Buchloh, "Figures of Authority, Ciphers of Regression: Notes on the Return of Representation in European Painting," October 16 (Spring 1981): 39-68; Douglas Crimp, "The End of Painting," October 16, (Spring 1981): 69-86; Thomas Lawson, "Last Exit: Painting," Artforum 20, no. 2 (October 1981): 40-47; Craig Owens, "Back to the Studio," Art in America 70, no. 1 (January 1982): 99107.

${ }^{56}$ Isabelle Graw, "Conceptual Expression: On Conceptual Gestures in Allegedly Expressive Painting, Traces of Expression in Proto-Conceptual Works, and the Significance of Artistic Procedures," in Art After Conceptual Art, eds. Alexander Alberro and Sabeth Buchmann (Cambridge, MA, London and Vienna: MIT Press and the Generali Foundation, 2006), 123, 128.

${ }^{57}$ Barton, interview with the author, 16 July 2020.

${ }^{58}$ Andrew Clifford, "Subterranean Grey Lynn Blues," in Certain Words Drawn: John Reynolds Continued, ed. Laurence Simmons (Auckland: Godwit, 2008), 265; Christina Barton, "After-Words," 8. ${ }^{59}$ Christina Barton, "After-Words," 8.

${ }^{60}$ An engraving of Charles Heaphy's Committee at Patapata was published as "Conference of Lieutenant-Governor Wynyard and Native Chiefs in Coromandel Harbour. The New Zealand Gold Field," Illustrated London News, 1853.

${ }^{61}$ Christina Barton, "After-Words," 14.

${ }^{62}$ Reynolds designed the covers for Blam Blam Blam's 1981 single "Don't Fight it Marsha, This is Bigger than Both of Us," their only full-length album Luxury Length, 1982, and the retrospective The Complete Blam Blam Blam, 1992. See Laurence Simmons, ed., Certain Words Drawn: John Reynolds Continued (Auckland: Godwit, 2008), 479.

${ }^{63}$ Blam Blam Blam, "There is No Depression in New Zealand," lyrics by Richard Von Sturmer, single released by Propeller Records, July 1981.

${ }^{64}$ Curnow perceives punk's influence primarily in antagonistic post-object art of the 1970s, and then again in the grunge-oriented work of the Teststrip collective in the early 1990s. I would argue, with McAuliffe, that punk's influence also continued through the intervening years of the 1980s. Wystan Curnow, "The Seventies: Have They Reached Their Use-by Date?" in The Critic's Part: Wystan Curnow Art Writings 1971-2013, ed. Christina Barton, Robert Leonard and Tomasin Sleigh (Wellington and Brisbane: Adam Art Gallery and Institute of Modern Art, 2014), 408-15; Chris McAuliffe, "Let's Talk About Art: Art and Punk in Melbourne," Art and Australia 34, no. 4 (Summer 1997): 502-12.

${ }^{65}$ Paul Taylor, “Australian 'New Wave' and the 'Second Degree,"” Art \& Text 1 (Autumn 1981): 23-32.

${ }^{66}$ McAuliffe, "Let's Talk About Art," 505.

${ }^{67}$ Johnstone "Foreword," 9. 